Volume 11 Number 2, April-June 2017: pp. 97-108, Copyright (c) 2017 FIAT JUSTISIA. Faculty of Law, Lampung University, Bandarlampung, Lampung, Indonesia.

ISSN: 1978-5186 | e-ISSN: 2477-6238.

Open Access: http://jurnal.fh.unila.ac.id/index.php/fiat

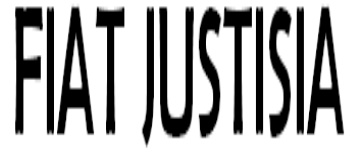

Justisia is licensed under a Creative Commons Attribution 4.0

International License, which permits unrestricted use,

distribution, and reproduction in any medium, provided the

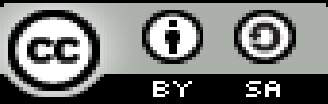

original work is properly cited.

\title{
The Choice of Law Issues in Marine Insurance Disputes Resolution in Indonesia
}

\author{
Marnia Rani \\ Department of Law, Universitas Maritim Raja Ali Haji \\ marniarani@umrah.ac.id
}

\begin{abstract}
Marine insurance business in Indonesia such as marine hull and machinery insurance and cargo insurance are subject to applicable laws and practices in the United Kingdom. Although Indonesia already has marine insurance law which is regulated in Wetboek van Koophandel, in fact, this business subject to English Law and Practice. The choice of law is listed in the insurance policy. Submission of the law and practice in the UK raises the issue for the parties in the insurance contract, between Insurer and Insured. Although the principle of the contract is a law for those who make it, in practice, there is a problem. The problem is especially when there is a dispute between Insurer and Insured. When disputes occur, each party has a different opinion regarding which country's laws may be applied to resolve disputes between Insurance Companies and Policyholders (the proper law of the contract, the applicable law). When referring to the provisions contained in the marine insurance policy which is a contract of the parties, it should be settled under the legal system and the practice of law which is in force in the United Kingdom, because the choice of law is written in the contract. However, the problem arises again, whether the choice of law in the insurance contract can be applied, if the insurance company as a legal entity is established under Indonesian law and domiciled in Indonesia, as well as the policyholders who are Indonesian. On the basis of such matters, this paper intended to elaborate the principles of international civil law in Indonesia regarding the choice of law in the contract and is also associated with the personal status of the insurance company, the personal status of the policyholder who are Indonesian, as well as the consequences of the choice of law listed in marine hull and
\end{abstract}


machinery insurance or cargo insurance and national laws which can be applied to marine insurance disputes occurring in Indonesia.

Keywords: Marine Insurance, Choice of Law

\section{A. Introduction}

Nowadays, the business transaction activity is growing by involving foreign companies that establish or open business in the territory of The Republic of Indonesia. With the establishment of such a foreign business entity, it brings consequences to the choice of law that is selected as a dispute resolution mechanism. Such foreign business entities generally choose national law from their own country of origin as a choice of law and choice of forum. In fact, not only that, but there are also Indonesian corporations choosing the national laws of other countries as well as the jurisdiction of other countries forums, as a dispute resolution mechanism among them.

Essentially, the choice of law is closely related to the basic principle of making a contract, namely freedom of contract (party autonomy). This is as stated by Sudargo Gautama that the choice of law is the freedom that is granted to the parties in the contract to choose for themselves the law to be used. The parties have the freedom to choose the law that will be applied in the contract (the proper law of the contract, the applicable law). ${ }^{1}$ The choice of law of dispute resolution generally has been listed in the standardized contract of business by product and service bidders. It is because the companies producing products or services have the discretion to determine the choice of law unilaterally in the standardized contract. The standardized contract has been made, making the consumer accept what has been arranged in the contract or not accepted by not signing the contract (take it or leave it). In the end, the freedom of contract, in reality, is not always applicable, because it is more focused on the interests of the company producing products or services.

The business contract made in the standardized contract has been determined by choice of law and the choice of the jurisdiction of the dispute resolution of the parties. Although, the consumer does not agree or does not unaware of any choice of law clause subject to the law of another country. If it agrees by signing the contract, then it makes the consumer declares subject to the choice of law that are listed in the contract. Similarly, marine insurance contracts in Indonesia, such as the marine hull and machinery policy and marine cargo policy, the choice of law has been determined that

\footnotetext{
${ }^{1}$ Sudargo Gautama, Hukum Perdata Internasional Indonesia Jilid III Bagian 4 Buku ke-5, Bandung: Alumni, (1998), p. 5.
} 
the parties are subject to the laws and practices in the UK insurance business practice (subject to English Law and Practice). ${ }^{2}$

Theoretically, if the parties to the contract have determined the choice of law to be subject to a particular legal system, then the dispute should be resolved according to the chosen legal system. Submission to the laws and customs of the English Law raises a problem for the parties in the insurance contract, for example between the insurance company and the policyholder, especially when there is a dispute between the two. The insurance company considers if the choice of law in the insurance contract has been determined to subject to the laws and customs of the insurance business in the UK, then the law is material and formal, the dispute is resolved under The English Law and The English Courts. However, the Policyholder who suffers a permanent loss has filed a lawsuit against the court in the territory of the Republic of Indonesia, because in the principle of the contract, the law is for the parties who make it. It is recognized in the contract law in Indonesia. ${ }^{3}$

The choice clause of law in the contract is important to provide legal certainty in the resolution of disputes between the parties. Huala Adolf states that the choice of law clause serves to determine what law is used to establish the terms of the contract, avoid the legal uncertainty applicable to the contract, and be a source of law when the contract does not regulate certain matters. ${ }^{4}$ The study of Private International Law, especially about the contracts, the choice of law and the choice of forum issues are often being misunderstood; sometimes there is a presumption that the choice of law is the same as the choice of forum, whereas both are different. The choice of law regarding the choice of the parties to choose the material law and the choice of forum is related to the choice of dispute resolution forum among the parties. The parties may choose a court or arbitration forum or another forum. ${ }^{5}$

Although in theory, the laws and customs of the insurance business in the UK are enacted by contract, in practice it is not necessarily applicable. It is because the parties to the contract are domiciled in the jurisdiction of Indonesia and status as a legal entity is established under Indonesian law.

\footnotetext{
${ }^{2}$ Marine Hull Policy and Marine Cargo Policy PT Asuransi Jasa Indonesia (Persero).

${ }^{3}$ Article 1338 Paragraph (1) The Civil Code Indonesia (Burgerlijk Wetboek).

${ }^{4}$ Huala Adolf, Dasar-Dasar Hukum Kontrak Internasional, Bandung: Refika Aditama, (2007), p. 139.

${ }^{5}$ Muhammad Risnain, 2014, Problematika Pilihan Hukum (Choice of Law) in "Penyelesaian Sengketa Transaksi Bisnis Elektronik Internasional" in "Undang-Undang (UU) Nomor 11 Tahun 2008 Tentang Informasi dan Transaksi Elektronik", Monograf Dimensi Hukum $\begin{array}{llll}\text { Internasional Volume } & 2 & \text { Tahun }\end{array}$ http://jurnal.fh.unila.ac.id/index.php/monograf/article/view/638, p. 213.
} 
Under such conditions, ultimately creates legal uncertainty for parties to marine insurance contracts.

On the basis of such matters, this paper intends to describe the principles of international civil law in Indonesia regarding the choice of law in an insurance contract that is attributed to the personal status of an insurance company, the personal status of Indonesian and Indonesian policyholder, and the consequences of the choice of law that are listed in marine insurance contracts, as well as determining which country's legal system is applicable to marine insurance disputes that occur in Indonesia, so as to provide legal certainty for insurance companies and policyholders in resolving marine insurance disputes in Indonesia.

\section{B. Method}

This research belongs to explanatory legal study, which aims to explain and test the theory of the choice of law is linked to the conditions that occur in the reality of the practice in the judiciary. The problem approach that is used is the approach of legal analytical normative (the approach of legal content analysis), by using the type of legal analysis. ${ }^{6}$ The juridical approach is conducted by studying and examining theories, concepts, legal doctrines and legislation that are related to the problem.

The type of data that is used is secondary data. This secondary data consists of primary legal materials, secondary legal materials, and tertiary legal materials. The source of the primary law that is used is Algemene Bepalingen van Wetgeving $(\mathrm{AB})$, which regulates the principles of the International Civil Law in Indonesia regarding the choice of law in a contract. Secondary law materials that are used is to explain the primary legal materials, the results of research or opinion of legal experts are contained in the law books. Tertiary legal materials are taken from the law journals and the electronic media on the law. The data has been collected from existing, processed and analyzed legal materials, resulting in a conclusion and legal certainty for the parties regarding the choice of law and forum choice in the dispute of Marine Insurance in Indonesia.

\section{Discussion}

The choice of law (the law applicable to the contract) is a classic problem that is never ceased to be the subject of law. The issue of choice of law is a matter that is not easy. The others may not necessarily accept a law that is chosen by one party. Even if the law is finally selected, it does not mean there is no problem. There are many reasons whether the court will

\footnotetext{
${ }^{6}$ Abdulkadir Muhammad, Hukum dan Penelitian Hukum, Bandung: Citra Aditya Bakti, (2004), p. 113.
} 
apply the choice of law or not. Sudargo Gautama states that the issue of choice for this law is a matter that is still controversial. There is a different opinion that does not allow the realization of unanimous legal certainty. ${ }^{7}$

The choice of law clause is the choice clause of the legal system that is chosen by the parties to govern the contract. Often many parties equate the choice of law with the choice of forum. Whereas, the choice of law concerning the law applicable to a contract, while the choice of forum concerning the choice of jurisdiction is authorized to examine or adjudicate the dispute that is occurred. However, there are also certain countries, which courts hold that if the parties elect a particular legal entity, the applicable law shall be the national law to which the court is situated. This means that the court is of the opinion that the automatic choice of law is also the choice of forum. The courts in England share the view. ${ }^{8}$

Essentially, the doctrine of choice of law is the application of the principle of freedom of contract, which gives freedom to the parties to determine the legal system to be applied in the contract. However, in today's fast-paced business development regarding time efficiency, many business people apply their standardized contract offerings to make it easier for parties to complete the contract approval process between them. In the same way as the Marine Hull Insurance and the Marine Cargo Insurance business in Indonesia, marine insurance contracts have been made in raw and have become a habit in this type of business, the clauses in the marine insurance contract are legally and customary in UK Law (subject to English Law and Practice).

The choice of law to be subject to the laws of other countries in the marine insurance business in Indonesia, bring this business into the reality of Private International Law especially when there is a dispute between Insurance Company as Insurer and Policy Holder as the Insured. On the other hand, the problem is whether the dispute between the Insurance Company and the Policyholder can be said to be a dispute concerning the International contract, simply because of the choice to comply with the choice of laws and customs in the UK, while the parties to the dispute are domiciled in Indonesia and established by the Indonesia Law.

A problem may be expressed as a dispute in the field of International Civil Law, where the legal facts, in this case, indicate a connection with a foreign jurisdiction. In connection with the marine insurance business that is undertaken in Indonesia, it is used to determine whether disputes between

\footnotetext{
${ }^{7}$ Sudargo Gautama, Hukum Perdata Internasional Indonesia Jilid III Bagian 2 Buku ke-8, Bandung: Alumni, (2013), p. 2.

${ }^{8}$ Clive M Schmitthoff, International Trade Law and Private International Law, (1988), As cited by Huala Adolf, Dasar-Dasar Hukum Kontrak Internasional, Bandung: Refika Aditama, (2007), p. 138.
} 
the parties are included in the scope of the International Private Civil Law study. When it is assessed by using the Point Theory, then it can be seen from the place of the parties in the marine insurance contract. Based on The Primary Linking Point Theory, if the parties are consisting of insurance companies and policyholders that are domiciled in the jurisdiction of the Republic of Indonesia, it can be concluded that the marine insurance dispute is not included in the reality of events, which are related to the International Civil Law. However, according to the customs in the marine insurance business in various countries, the choice of special law for marine insurance business must be subject to the laws and customs in the UK, and then it can be legal events that are related to marine insurance disputes, which are categorized as events that fall within the domain of Private International Law. $^{9}$

Although it is legally eligible, the marine insurance business in Indonesia is subject to the laws and customs in the UK, it is not necessarily applicable in Indonesia, since every dispute in the field of marine insurance in Indonesia is filed with a lawsuit to a domestic court in Indonesia, in accordance with the jurisdiction of the defendant, in this case, is the insurance company. There are different views by Judges in Indonesia on the choice of law that are listed in marine insurance contracts. There is a view that the choice of law, brings the consequences for the parties to submit to English law, both material law and formal law. But there is also a view that is not, distinguish between the law that is applied for the settlement of substance with formal law.

It can be seen from some of the existing Court decisions in Indonesia that are related to marine insurance (Marine Cargo Insurance, Marine Hull Insurance). On the Supreme Court Decision Number 1011K/Pdt./2009, PT Mega Agung Nusantara against PT Asuransi Harta Aman Pratama, Tbk. PT Mega Agung Nusantara as Plaintiff is a company engaged in the field of goods trading business (machine) domiciled in Jakarta, Indonesia and get Project Genset Procurement from the Directorate General of Electricity and Energy Utilization Ministry of Mineral Resources Republic of Indonesia. To reduce the risk of loss in the event of carriage of goods, PT Mega Agung Nusantara insured their stuff on PT Asuransi Harta Aman Pratama, Tbk by Policy Number 04.12.118.00945. On the way of transportation from the port of Ambon to the Port of Wayana and then to Tual by truck, an accident caused the generator set to roll over. Due to the accident, it caused the losses that were experienced by PT Mega Agung Nusantara. To cover the losses

\footnotetext{
${ }^{9}$ R. Fajriyansah, A Study Of The Application Of Utmost Good Faith Principle Under The English Marine Insurance Law: Legal Review And Practical Solutions, (2005), http://commons.wmu.se/cgi/viewcontent.cgi?article=1220\& context=all_dissertations, downloaded May 19, 2017.
} 
that were suffered by PT Mega Agung Nusantara then filed a claim for compensation payment in PT Asuransi Harta Aman Pratama, Tbk as Insurance Company which was bound by insurance contract with Plaintiff. However, PT Asuransi Harta Aman Pratama, Tbk that is domiciled in Central Jakarta, rejects the claim for compensation to be paid by the policyholder, for one reason that the insurance contract between the Insurance Company and the policyholder is subject to English law, and the prevailing practices in UK Insurance is Subject to English Law and Practice). By that, the Defendant (Insurance Company) concludes that the dispute should be settled under the English law and submitted to the court in the UK. The judge denies the opinion of Insurance Company by rejecting the Plaintiff's claim against Central Jakarta District Court Decision No.11/Pdt.G /2007/PN.Jkt.Pst that Central Jakarta Court is not authorized to examine and adjudicate the case. The decision of Central Jakarta District Court was strengthened at appeal level by the Jakarta High Court Decision No.318/Pdt/2008/PT.DKI and appealed by Supreme Court Decision No.1011K/Pdt/2009.

It is different from the Central Jakarta District Court Decision No.51 /PDT.G/2010/PN.JKT.PST. PT Pelayaran Manalagi as the Plaintiff against PT Asuransi Harta Aman Pratama, Tbk as the Defendant. The Plaintiff is domiciled in Surabaya, and the Defendant is domiciled in Jakarta. Thus both parties are equally domiciled in the jurisdiction of the Republic of Indonesia. Plaintiff and Defendant have agreed on Marine Hull and Machinery Insurance with Policy Number 03.08.05.10.82710025, with the object of Cargo KM Ship Insurance. Bayu Prima from Port of Tanjungperak Surabaya to Batu Ampar Port Batam and Belawan Port of Medan. By the time KM Bayu Prima is anchored in the port of Batu Ampar Batam, a fire that causes the ship must be beached. PT Pelayaran Manalagi filed a claim for Total Loss payment to PT Asuransi Harta Aman Pratama Tbk. However, PT Asuransi Harta Aman Pratama rejects the claim for compensation payment that is submitted by PT Pelayaran Manalagi as by the Insurance Policy; the parties agree to submit to the English law (This Insurance is Subject to English Law and Practice). Thus, the Central Jakarta District Court is not authorized to examine and adjudicate the cases, since the authorities are in UK courts. However, in this case, the Panel of Judges holds another view from the Defendant's view, according to the Panel of Judges that the choice of law with the choice of jurisdiction or the choice of authority to adjudicate are two different things, even in the Insurance Policy Number 03.08.05.10 .827 .00025 has been agreed on the provisions of UK law governing it, but in the policy is not regulated on the jurisdiction of the court which is authorized to hear if there is a legal issue in connection with the Insurance Policy, then the Plaintiff's choice of which Court will examine and adjudicate the case is 
based on the fact that the contract is made and executed in Indonesia, the object of the coverage of the Indonesian-flagged vessel, accident or fire that is occurred in Indonesia, the Court is authorized to examine and adjudicate the dispute that present in Indonesian, in this the case of Central Jakarta Court based on the civil procedure law is contained in the HIR because the Plaintiff chose the domicile of the Defendant in Central Jakarta District Court (Art. 118 HIR).

Based on these two cases, there are different opinions by judges in examining, hearing and deciding cases. In the first case, the judge decides that the district court until the Supreme Court is not authorized to examine, hear and decide cases. In the second case, the panel of judges is about the opinion that the choice of law and the choice of jurisdiction are two different matters so that the courts in Indonesia are authorized to examine, hear and adjudicate cases filed in the jurisdiction of Indonesia. The difference of opinion of judges in both cases in deciding the dispute in the field of marine insurance, in which the marine insurance contract in Indonesia is subject to the laws and customs in the UK, causing legal uncertainty.

The study of Private International Law relating to the choice of law and the choice of forum in a contract is important to anticipate the occurrence of disputes arising in a contract, so there is no misunderstanding in the use of both terms. Sometimes the choice of law is the same as the choice of forum, when in fact it has a striking difference. The choice of the law regarding the choice of the parties to choose a particular law which they subject themselves to in the contractual act and the settlement of the contractual matter whereas, the choice of the forum is related to the choice of dispute resolution forum that is chosen by the parties to resolve the case among those who may just choose a court forum or forum others. ${ }^{10}$

Sudargo Gautama draws a clear boundary between the choice of law and the choice of forum. ${ }^{11}$ Similarly, Huala Adolf premises that the choice of law and choice of forum or choice of jurisdiction are in different fields. If in the choice of law of the parties determine Indonesian law, not necessarily for the court to handle the issue in Indonesian, and vice versa if in the choice of law choose Indonesian law then the court that is authorized to solve the case in Indonesian as a choice of forum. Likewise, if the parties choose Indonesian as a choice of the forum then it is not the choice of law is Indonesian, too. However, the parties are granted the freedom to choose laws and forums in a particular country, to select Indonesian law and to select an Indonesian Court forum. ${ }^{12}$

\footnotetext{
${ }^{10}$ Muhammad Risnain, Op. Cit, p. 213.

${ }^{11}$ Sudargo Gautama, Op. Cit, p. 2.

${ }^{12}$ Huala Adolf, Op. Cit, p. 165.
} 
The choice of forum in a contract that has a relationship with foreign elements is an anticipative step by the parties to anticipate future disputes in the contract implementation. The choice of the forum provides certainty for both parties to choose a dispute resolution forum and minimize the conflict of the authority of the dispute settlement institution in settlement of the dispute. In international civil law that is allowed to vote for a forum is a law concerning the effective law of non-procedural parties, procedural provisions follow the legal provisions that are contained in the court as a forum, which is chosen by the parties. ${ }^{13}$

Based on the two cases of marine insurance above, in which the judges have different opinions on the case, the author is more likely to agree on the legal considerations that are decided by the judges in the second case. Because however, when it is viewed from the status of the persona of the parties, who are involved in the dispute of a private person/legal entity is an Indonesian citizen or legal entity residing in Indonesia. The legal entity that is involved is domiciled and incorporated under Indonesian law.

The problem of choice of law and choice of forum in dispute in the field of marine insurance, to determine the law of the imposed state (the proper law of the contract, the applicable law) to examine the case, it can be studied from some classical theories in the dispute in the field of Private International Law, Theory of the first Theory of Choice of Law, Theory of Personal Status of Legal Entity, Theory of Points of Conjunction. The choice of law is very appropriate when it comes to contractual disputes. But still, it has to see the relation of legal entity or insurance company as a defendant with jurisdiction forum where the case is filled.

When it is viewed from the personal status of legal entities, Sudargo Gautama states that there are three theories there can determine, namely Incorporation Theory, Theory Statutair, and Theory Place Effective Management Position. According to the theory of incorporation (Inkorporationstheorie Grundungs-Incorporation principle), a legal entity shall be subject to the law in which it has been created, established, constituted (state of incorporation), a state whose law has been followed at the time of the formation of such body. Statute Theory, the applicable law is the law of the place where according to statute, the legal entity is domiciled. The theory of effective management is related to the place of the effective legal entity.

Also, it can be determined by using the personal theory of legal entities and can also be determined by using the principles applicable to material law. Marine insurance comprising Marine Hull and Machinery Insurance, Cargo Insurance, which becomes the object of coverage is ship

\footnotetext{
${ }^{13}$ Muhammad Risnain, Op. Cit, p. 216.
} 
and goods. In determining the law applicable to marine insurance issues, the ship belongs to the category of immovable objects, but its nature continues to move, the principle of lex rei site is not appropriate when it is applied to the ship. For objects in the form of a vessel, it is more appropriate to use the determinative point of view of the ship flag law, namely the law that determines the registration status of the vessel. As for the cargo that is moving, it can apply the law from where the holder of the right to the object is a citizen or law from the place of the holder of the right to the object is domicile (domicile principle).

Based on the above description, although the contract stated that the choice of law is subject to the laws and customs in the UK, but in the case, marine insurance cannot deny the existence of subjects (the parties in the cons) and the object of legal coverage that is closely related to the law in the region where the parties and objects, which are stipulated in the insurance contract. Similarly, the choice of judicial jurisdiction basically relates to the question of whether a court has sufficient connection to a defendant or property that is involved in a case, or underlying transactions of the case, as justification for the court's claim to try the case.

The fact that the courts in Indonesia do not have the same stance in examining and deciding cases in the field of marine insurance is related to the choice of law and the choice of forum. This is because one of them does not currently have an International Civil Law which explicitly regulates the Choice of Law and Choice of Forums. Judges and Lawyer also have no clear and definitive reference in the face of cases that are related to foreign elements.

\section{Conclusion}

The marine insurance business in Indonesia, which is contractually subject to existing laws and customs in United Kingdom, makes it difficult for parties to insurance contracts to address such choice of law the event of a dispute between them. Insurance companies, with the opinion that, if the insurance contract has been determined by choice of law to comply with UK insurance law, then both material and formal must be settled under The English Law and in The English Court. It certainly makes it difficult for Policyholders who are domiciled in Indonesia, contracts, and object of insurance are in Indonesia. Therefore, it is not wrong if the judge decides that the case in the field of marine insurance is solved within the jurisdiction of the law in Indonesia based on the status of the persona of the insurance company, the insurance contract is created and executed in Indonesia, and the object of the insured object which the holder is domiciled in Indonesia and the object of the ship the Indonesian flag. 
The fact that the courts in Indonesia do not have the same stance in examining and deciding cases in the field of marine insurance is related to the choice of law and the choice of forum. This is because in Indonesia it does not currently have an International Civil Law which explicitly regulates the Choice of Law and Choice of Forums. Judges and Lawyer also have no clear and definitive reference in the face of cases that are related to foreign elements. Based on the principles of the International Civil Law in Indonesia, when referring to the principle of contract law, the choice of law should refer to the laws and practices customs that exist in the UK, then substantially (material law), every case in the field of marine insurance (marine hull and machinery insurance) should be based on English Law and applicable practice in the UK. However, the marine hull and machinery policy does not specify the choice of the jurisdiction of the courts or the jurisdiction of courts in Indonesia to examine and decide on seabed insurance cases.

When applying the principle of the International Civil Code in Indonesia regarding the status of the persona legal subject under Article 16 Algemene Bepalingen van Wetgeving (AB), namely insurance companies and policyholders, which is incorporated and established under the Indonesian law, the forum has the authority to settle the case in the jurisdiction of the court where the case is filed, in this case the Defendant's domicile. It is also by the principle of the place of incorporation stating that the status under which the legal entity is established. Based on Article 5 paragraph (2) of Law Number 25 The Year 2007 on Foreign Investment, The foreign investment shall be in the form of limited liability of a company under Indonesian law and domiciled within the territory of the Republic of Indonesia, unless otherwise provided by law. The Insurance company in Indonesia, although in the form of foreign investment, based by the place of incorporation and the Foreign Capital Investment Law, then if a dispute arises about marine insurance, it can still be resolved in Indonesian courts.

Similarly when referring to Article $17 \mathrm{AB}$ that governs the principle of fixed objects (non-movable), that the law applicable to fixed objects is the law of the country in which it is situated. In the case raised in this paper, the object of insurance coverage is an Indonesian flagship, accidents or fires occur in Indonesia, this means the insurance disputes can be settled in Indonesian courts. Based on the description above, the writer argued, although in the insurance contract specified choice of law refers to English law, because no choice of dispute resolution forum, then the Marine Insurance dispute may be settled through an Indonesian court with reference to Articles 16 and $17 \mathrm{AB}$, which sees the personal status of the legal entity of the insurance company established under Indonesian law and the object of 
the insured vessel of the Indonesian flag, then basically the marine insurance dispute in Indonesia can be settled through the courts in Indonesia.

\section{A. Book}

\section{Bibliography}

Adolf, Huala. (2007). Dasar-Dasar Hukum Kontrak Internasional. Bandung: Refika Aditama.

Gautama, Sudargo. (1998). Hukum Perdata Internasional Indonesia Jilid III Bagian 4 Bukum ke-5. Bandung: Alumni.

Gautama, Sudargo. (2002). Hukum Perdata Internasional Indonesia Jilid III bagian 2 Buku Ke-8, Bandung: Alumni.

Gautama, Sudargo. (2013). Hukum Perdata Internasional Indonesia Jilid III Bagian 2 Buku ke-8, Bandung: Alumni.

Latip, Yansen Dermanto. (2002). Pilihan Hukum dan Pilihan Forum dalam Kontrak Internasional. Jakarta: Program Pascasarjana, Fakultas Hukum Universitas Indonesia.

Muhammad, Abdulkadir. (2004). Hukum dan Penelitian Hukum. Bandung: Citra Aditya Bakti.

\section{B. Legislations}

Algemene Bepalingen van Wetgeving voor Indonesie.

Marine Hull Policy and Marine Cargo Policy PT Asuransi Jasa Indonesia (Persero).

The Civil Code Indonesia (Burgerlijk Wetboek).

\section{Journal}

Muhammad Risnain, "Problematika Pilihan Hukum (Choice of Law) dalam Penyelesaian Sengketa Transaksi Bisnis Elektronik Internasional dalam Undang-undang (UU) Nomor 11 Tahun 2008 Tentang Informasi dan Transaksi Elektronik", Monograf Dimensi Hukum Internasional, 2 (2014).

R. Fajriyansah, A Study Of The Application Of Utmost Good Faith Principle Under The English Marine Insurance Law: Legal Review And Practical Solutions 